\title{
Information Literacy of Library Science Students at the Faculty of Philosophy, University of Sarajevo
}

\author{
Lejla Hajdarpašić \\ Docent, PhD \\ Faculty of Philosophy, University of Sarajevo \\ E-mail lejla.hajdarpasic@ff.unsa.ba \\ Džejla Khattab \\ Senior Teaching Assistant \\ Faculty of Philosophy, University of Sarajevo \\ E-mail dzejla.khattab@ff.unsa.ba
}

This paper analyses information literacy competencies of students at the Department of Comparative Literature and Library Science, Faculty of Philosophy, University of Sarajevo that offers bachelor's degree and master's degree in library science. Survey on information literacy competencies of library science students at the Department was realized by the online questionnaire for self-assessment that was developed on the basis of Permutation Model Components with the purpose to obtain insight in student's perception of their information literacy competencies, to detect to what degree students improve their information literacy competencies and confidence during studies and what possible difficulties they face in this process. This is particularly important considering that there is no separate information literacy course adopted in Departments curricula but the information literacy related content is offered and taught in different courses. Analysis expectedly reveals that in general students feel confident in their information literacy competencies, that their information literacy competencies progressively improve during their studies, but also that students consider that the introduction of a stand-alone information literacy course would greatly contribute to the simpler and faster improvement of their information literacy competencies.

Keywords: information literacy; library science students; Faculty of Philosophy, University of Sarajevo

\section{Introduction}

The existing theoretical and practical literature in information literacy expectedly emphasizes the importance of proper acquiring of information literacy competencies from different perspectives, and especially when it comes to library and information science students. Library science students as future librarians also "have to be fully aware of the importance of IL as a concept, understand its relevance in contemporary societies and have to learn about main aspects of teaching IL" (Grgić\&Špiranec 2013). They have to continuously acquire information literacy competencies during their education considering that they will be the professional information mediators that will provide and teach information literacy. But when it comes to library science students, apart from acquiring these competencies, as Pinto and Pascual accentuates "two kinds of perceptions are key: belief in the importance of such competencies, and Self-Efficacy" (Pinto\&Pascual 2016).

Bandura (1997) explains that self-efficacy refers to "beliefs in one's capabilities to organize and execute the courses of action required to produce given statements" and that these beliefs "determine people's feelings, thoughts, motivations and behaviours" (Bandura 1986). Considering that high and low self-efficacy beliefs may result in achieving a certain task or its failure, measuring self-efficacy across different disciplines gained researches attention, including those in library and information science and consequently in information literacy. Self-efficacy might be understood as a highly effective predictor of students' motivation and learning and as the mediator of students' academic achievement (Zimmerman 2000).

Revista Română de Biblioteconomie şi Ştiința Informării = Romanian Journal of Library and Information Science ISSN 2559-5490, ISSN-L 1841-1940 • Volume 15 Issue 12019 pp. 8-15 https://doi.org/10.26660/rrbsi.2019.15.1.8

This work is licensed under a Creative Commons Attribution-NonCommercial-NoDerivatives 4.0 International License 
In the contemporary complex information environment, confidence, competencies and motivation play an important role in how a given task is undertaken, especially in new and challenging environments such as information retrieval systems through which heterogeneous users search and evaluate the information they need. Information-seeking and use have become challenging for university students due to the proliferation of information technologies and resources and they need strong information-seeking and use skills to accomplish their goals. While the higher education community has articulated the importance of information literacy competencies to assist students in learning to find, use and evaluate information, "low self-efficacy may be a significantly limiting factor for individuals exploring information problem-solving skills vital for lifelong learning" (Kurbanoglu 2004 p. 732).

\section{Literature review}

The first attempt towards designing a self-efficacy scale for information literacy was made by Kurbanoglu, Akkoyunlu and Umay (2004) who acknowledged that "attainment of high sense of self-efficacy beliefs is as important as possessing information literacy skills" and accordingly developed self-efficacy scale (ILSES) designed to measure self-efficacy for information literacy (Kurbanoglu, Akkoyunlu and Umay 2004). Similarly, by explaining that "a concept closely linked to motivation is that of self-efficacy", and that "students can become IL only if they proactively and independently choose to pursue the opportunities that are available to them during the course of their education", Pinto (2010) developed an information literacy self-assessment tool, the IL HUMASS questionnaire. Bronstein (2014) investigated the impact that the four sources of selfefficacy information (Bandura 1986) have on the self-efficacy beliefs of library and information science students, where results showed a high level of self-efficacy among LIS students. The role of information literacy self-efficacy in students' achievements has also been investigated by De Meulemeester (2013). The results of this research showed that students feel confident, but the IL test results, didn't indicate similar results (De Meulemeester 2013 p. 468).

Mentioned and other studies, reflections and discussions across different disciplines that were focused on the development of self-efficacy tools and were conducted in accordance to the Information Literacy Competency Standards for Higher Education by ACRL or other relevant standards and models, including national standards and models as well, resulted with many suggestions and contributions to these kinds of researches, but a common characteristic of different self-assessment approaches is the accentuation of the importance of information literacy as one of the essential competencies of future librarians that is inseparable from the concept of lifelong learning.

\section{Problem statement}

Considering that there is no separate information literacy course adopted in Department of Comparative Literature and Library Science, Faculty of Philosophy, University of Sarajevo curricula, but the information literacy-related content is distributed across curricula, the main purpose of this paper was to obtain insight in students' perception of their information literacy competencies, to detect to what degree student improve their information literacy skills during studies, what possible difficulties they face in acquiring information literacy competencies in above explained circumstances.

A survey on the information literacy competencies of library science students was realized by the online questionnaire that was created on the basis of model called Permutation Model Components (PMC). PMC model is the first and only model that was created for the purposes of information literacy implementation at the University of Sarajevo and it is "a combination of concept based 
approach with elements of tools based approach" (Rašidović 2011). The model consists of four categories: 1) Content, 2) Skills, 3) Evaluation and 4) Education. Content category consists of general knowledge and knowledge from curriculum, Skills category includes elements of defining the scope and nature of the information needs, defining search strategies, searching for different information resources and redefining the search process. Evaluation category includes elements of selection, analysis and assessment, organization and synthesis of information, while Education category refers to knowledge about the use and presentation of gathered and selected information, ethical and legal principles of citation, preparation of bibliographies, knowledge about citation styles, methods and elements of quoting (Rašidović 2011).

Previous research conducted on the basis of this model at the University of Sarajevo analysed information behaviour of the students at the Faculty of Philosophy, University of Sarajevo (Dizdar, Khattab and Grebović-Lendo 2016), experiences of the actual implementation of this model at the Faculty of Criminal Justice Sciences, University of Sarajevo, including pre-testing and testing of students information literacy competencies (Rašidović 2014, 2016) but no selfassessment studies based on this model were previously realized, so the development of this questionnaire for self-assessment should be recognized as a contribution to the implementation of this model in $\mathrm{BiH}$ environment and foundation of its further research and improvement.

\section{Research method}

The statistical population of the study were 50 BA (excluding first-year) and MA library science students at the Faculty of Philosophy, University of Sarajevo. The population sample presents students enrolled in the fall semester final exams, according to Student Information System of University of Sarajevo. Survey on the information literacy competencies of library science students at the Faculty of Philosophy was realized by the questionnaire that was created in the Google Docs platform. Data was collected by an online questionnaire consisting of 30 questions divided in 3 main categories and constructed on the basis of the 5-point Likert scale (1 - disagree, 5 - strongly agree) which was distributed to all 50 BA (excluding first-year students) and MA government-funded and self-funded students on 18 January 2019. A total of 42 students participated in survey, were all 42student provided complete answers. For validity, the questionnaire was distributed to a group of Library Science faculty members and experts. The questionnaire was amended based on their views and distributed to the participants.

Apart from the central part of questionnaire that consists of four to six questions in each above explained categories of the PMC, survey was used to gather open-ended questions, as well as personal and demographic information.

\subsection{Research findings}

From the total number of 42 respondents that participated in the online survey, $87.5 \%$ were female and $12.5 \%$ male. $38.1 \%$ of the respondents were BA and $59.5 \%$ MA students, $58.5 \%$ were government-funded students, and $41.5 \%$ self-funded students. Most of the students that participated in the survey, study double major in Library Science and Comparative Literature (46.2 $\%$ ), while others study double major in Library Science and History of Arts (14.6\%) or Education (7.2\%), Latin Language (4.8\%) or Roman Languages (4.8\%) and Oriental Philology (4.8\%) as well.

Apart from learning about information literacy-related content across curricula,57.1\% of respondents attended the information literacy program in the library of the Faculty of Philosophy, and $47.6 \%$ of students claim that they were not enrolled in this program, and $19 \%$ claim that they were not informed about this program. Also, $52.4 \%$ of students claim that they additionally 
acquire information literacy competencies by means of self-learning, $14.3 \%$ by attending different seminars and trainings, $35.7 \%$ claim that during their studies they developed their information literacy competencies with the help of librarians, and $4.8 \%$ respondents consider to be well informed and educated about information literacy so they don't need to acquire these competencies outside the curricula.

When it comes to students' perception about their information literacy competencies, analysis of responses submitted within each PMC categories reveals interesting results in many aspects. These results vary depending on the study cycle and also on the type of double major study program that students enrolled in.

In first, Content category, in general, students feel quite confident in distinguishing primary, secondary and tertiary resources $(57.1 \%)$, they feel competent to use electronic $(69 \%)$ and print information resources $(66,7 \%)$, to use online catalogue $(73.8 \%)$, but only $50 \%$ of respondents strongly agree that they are competent to use databases. When compared to the other questions in this PMC category (for example, the use of online catalogue that has the highest rates), the level of their confidence decreases when it comes to the use of search engines, meta search engines and directories (only $47.6 \%$, see Figure 1).

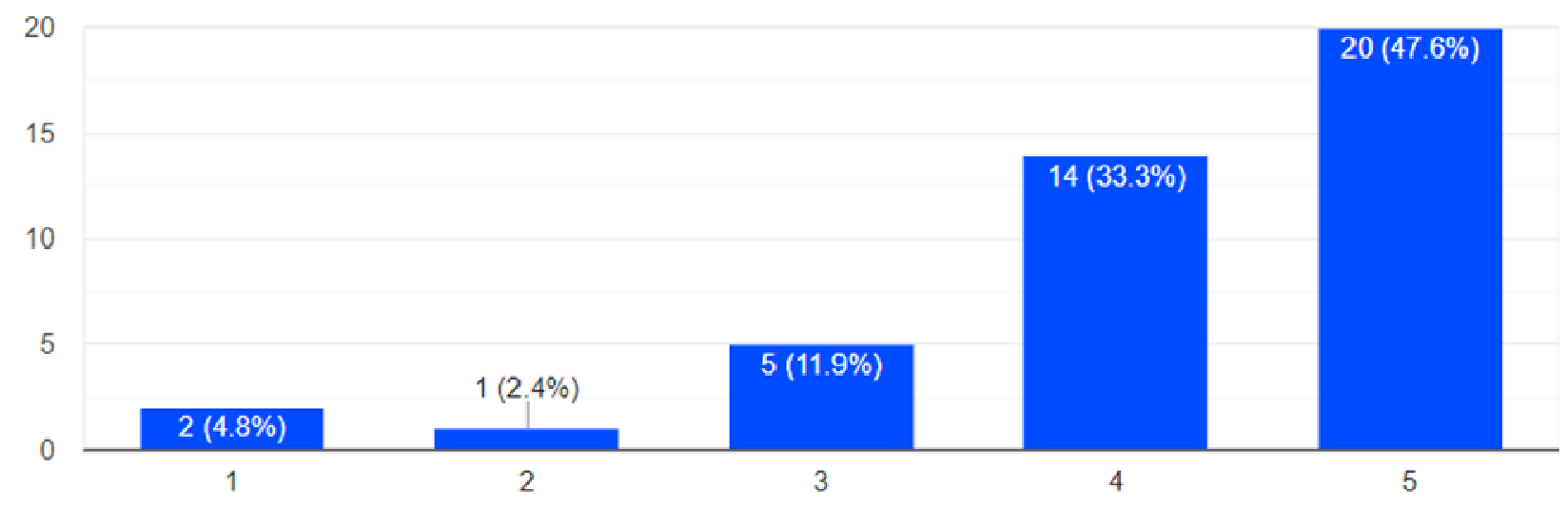

Figure 1. Content category: Use search engines, metasearch engines, directories, etc.

In contrast to the Content category, respondent answers in Skills category reveal lower selfefficacy beliefs. For example, only $31 \%$ of students strongly agree that they can define a search strategy, while $40.5 \%$ agree that they are confident in this segment. Additionally, $58.5 \%$ of students claim that they are most confident in using different search techniques and a small portion of $28.6 \%$ of students consider that they are very competent in redefining search strategy. Quite low ratings are detected in segment of defining information need. Only $38.1 \%$ of students strongly agree that they can define information need with no major difficulties, but both BA and MA students are most confident in searching for different information resources (Figure 2).

For the third PMC category, Evaluation, overall analysis indicates that $50 \%$ of respondents strongly agree that they can evaluate quality and credibility of information, also $50 \%$ students strongly agrees that they can evaluate information critically. $52.4 \%$ of respondents feel very confident in selecting relevant information, $47.6 \%$ in organizing information, while only $45.2 \%$ strongly agree that they can consolidate gathered information with no difficulties (Figure 3 ). 


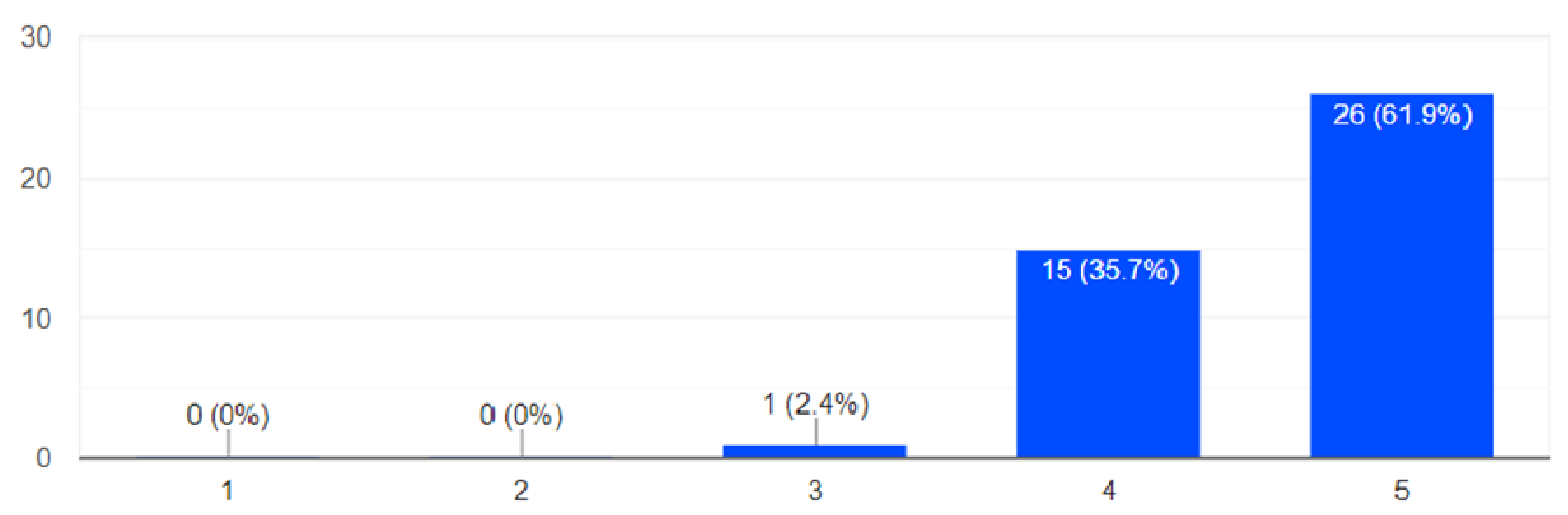

Figure 2. Skills category: Search for different information resources

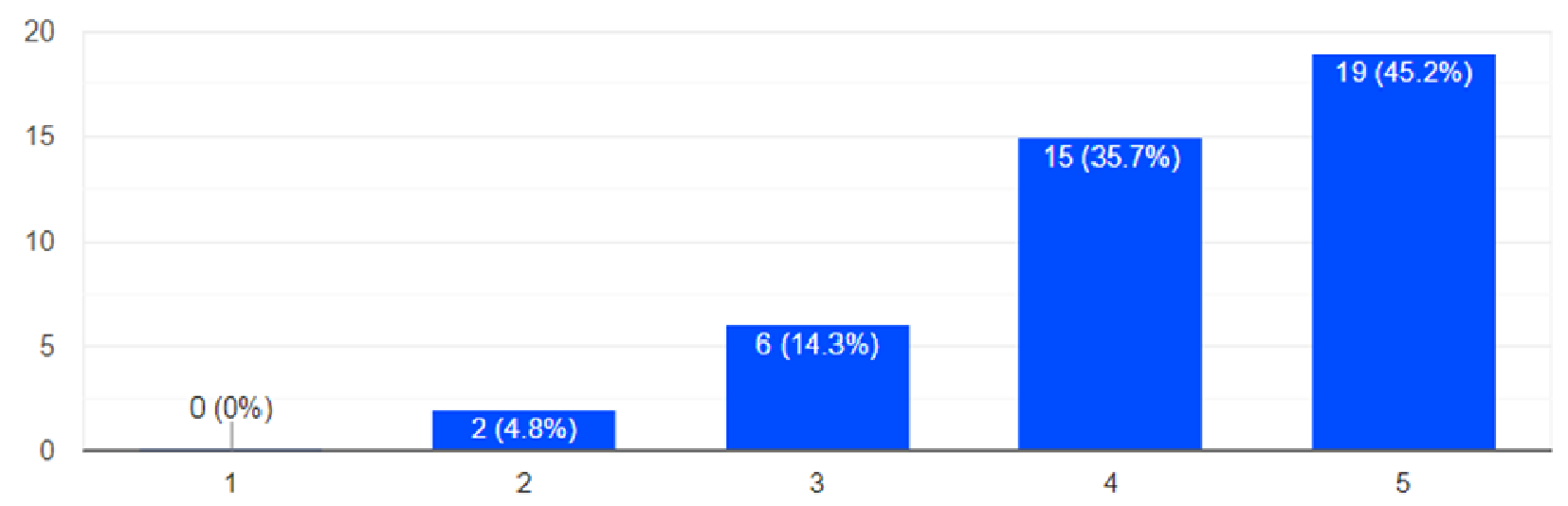

Figure 3. Evaluation category: Synthesize the evaluated information

Finally, for the Education category, 26.2\% feel very competent to use, present and disseminate selected information in different forms. Also, only $9.8 \%$ consider themselves very competent to use different reference manager software (Mendeley, EndNote and others). 52.4\% strongly agree that they can create bibliographic references for different information resources, while $76.2 \%$ of students strongly agree that they can cite information resources (Figure 4).

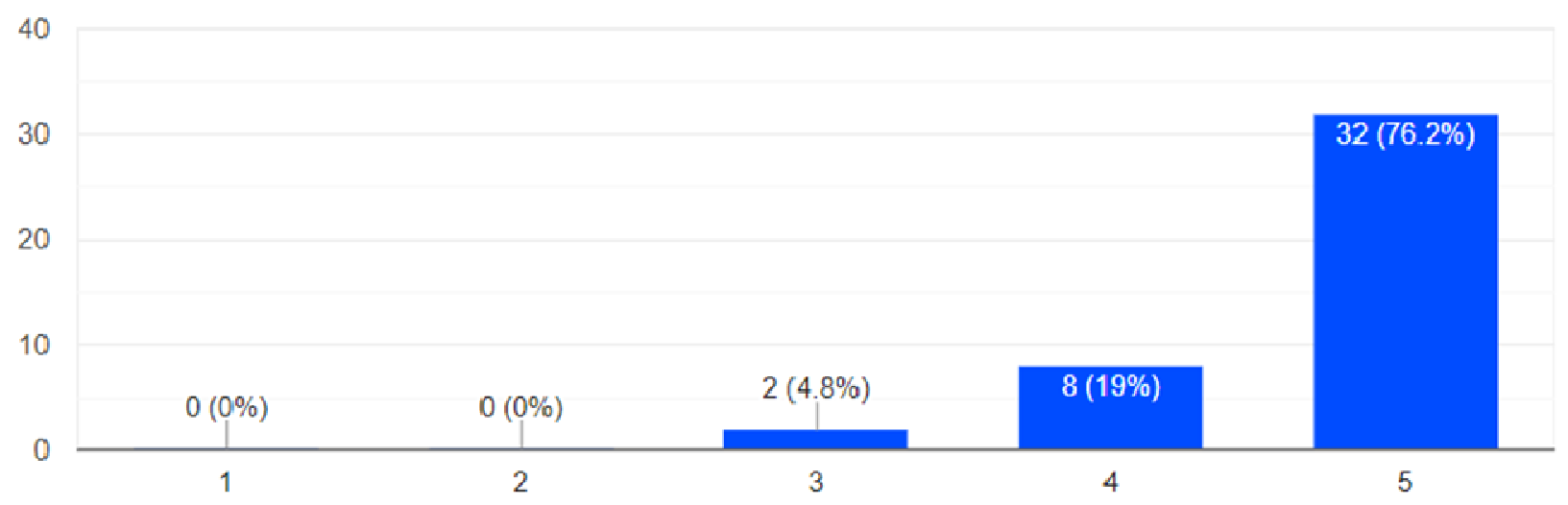

Figure 4. Education category: Make citations, quotations and to paraphrase 


\subsection{Research analysis and discussion}

As noted above, the students' perception about their information literacy competencies is mainly determined by the study cycle and also by the type of double major study program that students are enrolled in. In this regard, BA students, expectedly, have to a certain degree lower self-efficacy beliefs while MA students are very confident in their information literacy competencies in each PMC category. Also, the analysis indicates that students that enrolled double major in Comparative Literature and Library Science are more confident in each skills category and aware of their roles as future librarians, in contrast to students that enrolled double major in Library Science and other study programs at Faculty of Philosophy.

In general, most of the students consider that their information literacy competencies in Content category and Evaluation category are high. In Skills category quite low ratings are detected in segment of defining information need, and in Education category only a small number of students consider themselves very competent to use different reference manager software (RA 4).

Accordingly, when students were asked to what extent would they improve self-confidence and information literacy competencies by attending mandatory and independent information literacy course within the curriculum, only $2.4 \%$ students replied that they would not benefit from introduction of a standalone information literacy course. This actually correlates with answers provided in regard to what extent students feel competent to educate others about information literacy, were only $19 \%$, mostly MA students, feel completely confident to educate others about different aspects of information literacy (Figure 5).

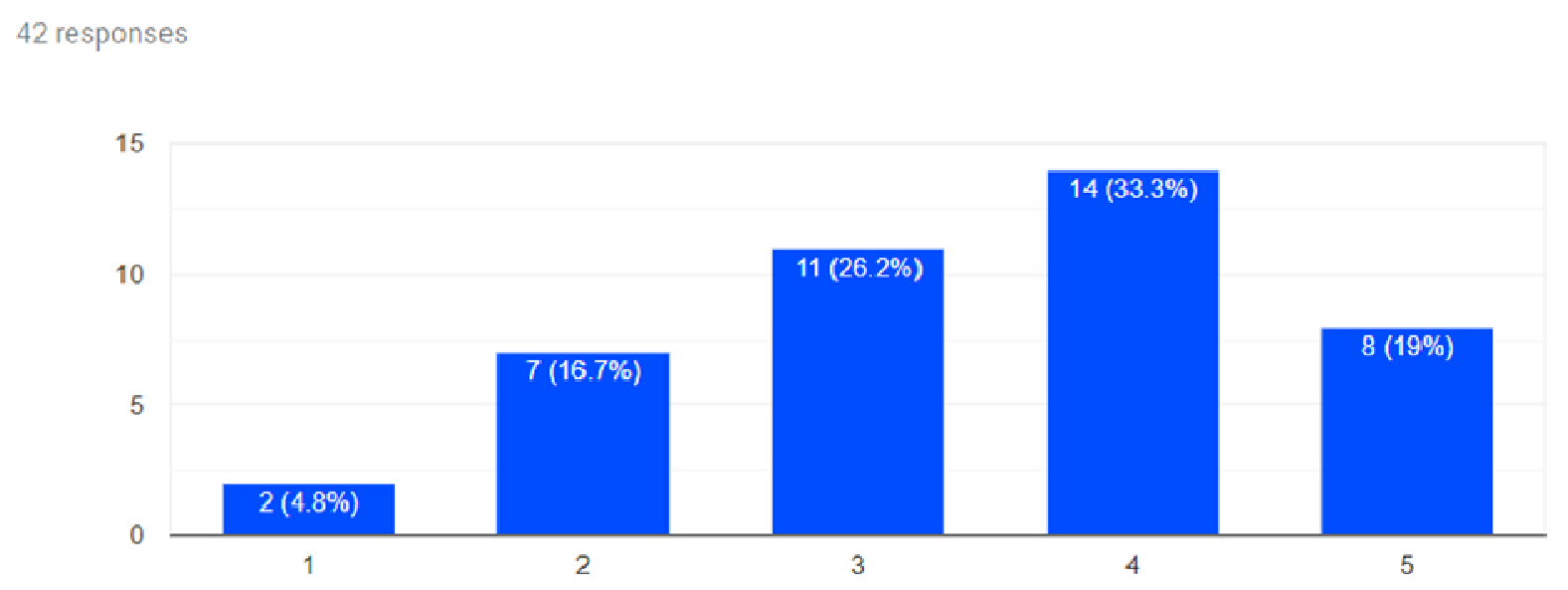

Figure 5. Level of competency in teaching IL to others

BA and MA students also had the opportunity to comment different questions and they submitted a total of 23 comments about the importance of information literacy. In general, in these comments, students accentuated that the information literacy competencies are crucial competencies of the contemporary society, but in comments provided, strong awareness about the important roles and responsibilities of librarians as educators of information literacy is partially missing when it comes to BA students.

\section{Conclusion}

Self-efficacy in relation to information literacy has also been explored in different scientific contexts and disciplines. The purpose of this survey was contribute to these kind of researches by developing self-assessment questionnaire based on PMC model, and consequently to obtain insight 
in library science students' perception of their information literacy competencies, to detect to what degree students improve their information literacy competencies and confidence during studies, what possible difficulties they face in this process, considering that there is no separate information literacy course adopted in Department of Comparative Literature and Library Science curricula but the information literacy related content is offered and taught in different courses.

Answers provided by library students in all four categories of PMC model indicate that in some segments library science students have low self-efficacy beliefs in terms of their information literacy competencies which certainly requires the redefining of the information literacy content delivery practices. The survey indicates that further steps needs to be undertaken in order to provide appropriate delivery of information literacy related content, maybe in terms of creating and adoption of a standalone information literacy course in curricula, at the bachelor's level. Information literacy concepts should be unquestionably promoted outside the library science environment as well, by developing strategies for the delivery of information literacy content on the university level. In this process the contribution and engagement of information professionals from academic and professional community should be recognized as crucial.

\section{References}

Bandura, A. (1986) Social foundation of thought and action : a social cognitive theory, Englewood Cliffs, N.J.: Prentice Hall.

Bandura, A. (1997) Self-efficacy: the exercise of control, New York: Freeman.

Bronstein, J. (2014) The Role of Perceived Self-Efficacy in the Information Seeking Behavior of Library and Information Science Students, The Journal of Academic Librarianship, 40(2) pp. 101106, available: https://doi.org/10.1016/j.acalib.2014.01.010.

De Meulemeester, A. (2013) The "Information Literacy Self-efficacy Scale" and the Medical Curriculum at Ghent University, Communications in Computer and Information Science, 397 pp. 465-470, available: https://doi.org/10.1007/978-3-319-03919-062.

Dizdar, S., Khattab, Dž. and Grebović-Lendo, N. (2016) Understanding the Role of Libraries and Librarians in Information Literacy Implementation: Based on the Example of Students of the Faculty of Philosophy, University of Sarajevo, in Knežević, R. et al. (eds.) Proceedings: International Scientific Conference "Western Balkan Information Literacy" - Information Literacy in the Digital World, 8-11 June 2016, Bihać: Limerick Institute of Technology, Ireland, pp. 173178.

Gowri, P. and Padma, P. (2018) Sconul seven pillars model to test the information literacy skills of engineering students: a case study, Library Philosophy and Practice (e-journal), 1996, available: http://digitalcommons.unl.edu/libphilprac/1996.

Grgić, I.H. and Špiranec, S. (2013) Information Literacy of LIS Students at the University of Zagreb: Pros or Just Average Millennials, in Kurbanoğlu, S. et al. (eds.), Worldwide Commonalities and Challenges in Information Literacy Research and Practice, Cham: Springer International Publishing, pp. 580-587, available: https://doi.org/10.1007/978-3-31903919-0_78.

Kurbanoglu, S., Akkoyunlu, B. and Umay, A. (2004) Developing the information literacy selfefficacy scale, Journal of Documentation, 62(6) pp. 730-743.

Pinto, M. (2010) Design of the IL-HUMASS survey on information literacy in higher education: A self-assessment approach, Journal of Information Science, 36 (1) pp. 86-103, available: https:// doi.org/10.1177/0165551509351198.

Pinto, M. and Pascual, R. F. (2016) Exploring LIS Students' Beliefs in Importance and Self- 
Efficacy of Core Information Literacy Competencies, College \& Research Libraries, 77(6) pp. 703-726, available: https://doi.org/10.5860/crl.77.6.703.

Rašidović, B.E. (2016) Izborni predmet informacijske pismenosti "Bibliotečko-informacijske baze" u kurikulumu Fakulteta za kriminalistiku, kriminologiju i sigurnosne studije Univerziteta $u$ Sarajevu [Elective course of information literacy "Library and information science databases" in the curriculum of the Faculty of Criminal Justices Sciences, University of Sarajevo], Pregled, 57 (2) pp. 35-53.

Rašidović, B.E. (2016) Model prožimanja komponenti u curriculumu fakulteta za kriminalistiku, kriminologiju i sigurnosne studije univerziteta u Sarajevu [Permutation model components in the curriculum of the Faculty of Criminal Justices Sciences, University of Sarajevo], Zbornik radova Odsjekaza pedagogiju, 1(1) pp. 249-257.

Rašidović, B.E. (2014) Model prožimanja komponenti u curriculumu Fakulteta za kriminalistiku, kriminologiju i sigurnosne studije Univerziteta u Sarajevu [Permutation model components in the curriculum of the Faculty of Criminal Justices Sciences, University of Sarajevo], Juni na Uni, pp.54-63.

Zimmerman, B.J. (2000) Self-efficacy: An Essential Motive to Learn, Contemporary Educational Psychology, 25(1) pp. 82-91. 